\title{
Reformatory Concepts of Educational and Care Activities in Regards to Neglected Children in the Kingdom of Poland at the Turn of the 19th and 20th Centuries in Comparison with European Solutions
}

\begin{abstract}
After the January Uprising in the Kingdom of Poland, across half of the following century, industrial development was mostly connected with social reforms. One tragic consequence of it was the increase in the number of children without parental protection, juvenile beggars, tramps, young criminals and prostitutes. During the last thirty years of the 19th century it became a priority in the Kingdom of Poland to pay attention to the education and protection of children and teenagers from the poorest families. Numerous innovative and educational concepts were formulated at that time; some of them were used in centres for socially maladjusted young people, for instance in Studzieniec, Mariańska Wilderness or Struga, in centres for young prostitutes. The activity of educational centres and societies which organised the protection of children (for example, The National Society for the Prevention of Cruelty to Children) was given as an example.
\end{abstract}

Keywords: socially maladjusted young people, educational reforms, Kingdom of Poland

The intensification of urbanisation and industrialisation processes in the 19th century exacerbated the problem of neglected and abandoned children throughout Europe. The same was true of the five decades in the Kingdom of Poland after the January Uprising, where intensive social, demographic and cultural transformations had an impact on increasing the number of children deprived of proper parental care, underage beggars, vagrants, juvenile criminals and prostitutes. In the Kingdom, the inclusion of children and young people from underprivileged and poorest families in education and upbringing was considered a social priority ${ }^{1}$. Looking for ways to limit the scale of these disturbing phenomena, Polish social activists observed actions taken in Western Europe and in the United States, where during the 19th century many state-supported social organisations

\footnotetext{
${ }^{1}$ BOŁDYREW, A., "Społeczne inicjatywy na rzecz walki z patologiami w Królestwie Polskim na przełomie XIX i XX w.”, Studia Gdańskie, vol. 31, 2012, p. 254-256.
} 
were established, dealing with the neglected, abandoned, orphaned and socially excluded children. These organisations established care and educational institutions, created their own pedagogical work programmes, and conducted research on the conditions of destabilisation of family life.

Solutions employed in Western Europe, observed by Polish social and educational activists during their studies and travels abroad, were a source of inspiration for local initiatives. In the second half of the 19th and early 20th centuries, foreign solutions were widely discussed in pedagogical periodicals, women's magazines, social and cultural papers, as well as medical, legal and economic magazines. Articles were written about the activities of caring for and educating abandoned children, attention was paid to the problem of violence in the family environment and corrupting influence of the families that engage in negligence and manipulation, forcing minors to steal or beg. Legislation aiming at preventing neglect and violence, such as the act of parliament for the prevention of cruelty to children, which was adopted in England in 1894, was analysed. The principles of limiting and depriving the parents of their authority, as well as forms of foster care used in other European countries were also presented and discussed. Much attention was paid to the solutions adopted in France during the Third Republic ${ }^{2}$. In order to establish children's care and education associations in the Kingdom of Poland, much interest was paid to foreign organisations of this kind. A number of articles was written about the numerous children's organisations in France ${ }^{3}$, the Children's Care Societies established in 1878 in Madrid (Sociedad Protectora de los Niňos) and in 1880 in Milan (La Sociétà Italiana Per la Protezione Dei Fanciulli), the Association for the Care of Children Wandering the Streets of New York, and above all the associations for the prevention of violence against children, including the New York Society for the Prevention of Cruelty to Children established in 1874 and the National Society for the Prevention of Cruelty to Children, founded in $1884^{4}$.

The interest in the problems of neglected and abandoned children was a distinctive feature of the positivists' work, who regularly wrote about the family and social situation of the so-called "street children". This term was popularized in the last three decades of the 19th century by, among others, Eliza Orzeszkowa, who in a series of articles entitled “O niedolach dziecięcych" (On children’s misfortunes) published in 1876 in Tygodnik

2 L.L., "Pozbawienie rodziców władzy rodzicielskiej”, Gazeta Sądowa Warszawska, 1890, issue 15, p. 237-238; A.M., "Ograniczenie władzy rodzicielskiej. Skutki wyroków karnych zagranicznych”, Gazeta Sądowa Warszawska, 1896, issue 13, p. 205-206.

${ }^{3}$ In the 19th century in France, a number of institutions taking care of children, as well as single mother were established, including Société Protectrice de 1'Enfance, Société Nationale des Amis de l'Enfance pour la Propagation de 1'Allaitement Maternelle, Société Générale de Protection pour l'Enfance Abbandonnée ou Coupable.

${ }^{4}$ PIETKIEWICZ, Z., “Opieka społeczna. Dzieci”, Prawda, 1900, issue 47, p. 559; MOLDENHAWER, A., "Stowarzyszenia i instytucye zagraniczne opiekujące się dziećmi”, [in:] Niedole dziecięce, Warsaw, 1882, p. 8284; HEYWOOD, C., "Childhood and Children", [in:] Europe 1789 to 1914: Encyclopedia of the Age of Industry and Empire, ed. J. MERRIMAN, J. WINTER, vol. 1, Thomson Gale, Detroit 2006, p. 427-432. The first name of the organisation called The National Society for the Prevention of Cruelty to Children, which exists to this day, was The London Society for the Prevention of Cruelty to Children. 
Ilustrowany ("Illustrated Weekly") wrote about the poverty of families unable to provide basic needs for children and about various forms of neglecting children ${ }^{5}$. At the beginning of the 20th century, the term "street children" was commonly used in journalism", often interchangeably with "street kids", "morally neglected children" and "children of urban poverty", moreover, they were often referred to as "street Arabs" - a name given to them by French journalists. At the turn of the 19th and 20th centuries. these terms were used to denote underage vagabonds, beggars, orphans, homeless teenagers living without family care or help provided by any social institution, but first and foremost they meant all children from the poorest families, mainly in metropolitan environments, who formally grew up in their homes and spent most of their time outdoors in the streets, backyards, squares, among their peers, who had a decisive influence on their behaviour, system of values and knowledge of the world ${ }^{7}$. The aim of this article is to point out several issues connected with the concepts and social activities aiming at caring and educating children from the poorest and neglected communities in the Kingdom of Poland.

The situation of children deprived of proper care and education was discussed in expert magazines, as well as social and cultural press in the Kingdom of Poland over the course of the last four decades of the 19th century and at the beginning of the 20th century, trying to expand people's knowledge of the subject and increase and social sensitivity towards the fate of these children and the social implications of their neglect. In 1897 Głos (The Voice) reported that according to the estimates of Warsaw's Charity Society activists, there were 25-30 thousand "morally and mentally neglected children" living in Warsaw". Educators, teachers, as well as social and educational activists considered it a priority to organise social forms of care, upbringing and education aiming at prevention and protecting children from demoralisation. Proposals were made to establish institutions that would support the proper course of socialisation processes, prepare children from socially and morally neglected groups to participate in social life 9 .

Bolesław Prus devoted much attention to the situation of neglected children and youth ${ }^{10}$. In his Chronicles (Kroniki) he wrote about "street children" who learn "loafing, debauchery, and theft" ". He drew readers" attention to the situation of children who grew up in stuffy places, with atmosphere saturated with alcohol, and who were forced to pre-

${ }^{5}$ ORZESZKOWA, E., “O niedolach dziecięcych”, Tygodnik Ilustrowany, 1876, issue 15, p. 236.

${ }^{6}$ It was the title of a 1901 novel by Janusz Korczak. KORCZAK, J., Dzieci ulicy, Warsaw, 1901.

7 MOGILNICKI, A., Dziecko i przestęstwo, Warsaw 1916, p. 28.

8 “Z życia stowarzyszeń. Opieka nad dziećmi”, Głos, 1897, issue 3, p. 62.

9 Cf. e.g. "W obronie dzieci”, Głos, 1904, issue 17, p. 262; JASTRZĘBIEC, A., "Przytułek wychowawczo-poprawczy dla dziewcząt", Tygodnik Mód i Powieści, 1891, issue 13, p. 102; MOLDENHAWER, A., "Domy moralnie zaniedbanych dzieci", Zdrowie, 1896, issue 5-7, p. 290-312; POŁKOTYCKI, W., "Domy sierot", Zdrowie, 1896, issue 5-7, p. 259-265; "Nieletni przestępcy”, Gazeta Sądowa Warszawska, 1877, issue 14, p. 111.

${ }^{10}$ More on that subject: Cf. GAŁEK, C., Myśl pedagogiczna Bolestawa Prusa na tle pozytywizmu polskiego, Zamość 2005, p. 203-251.

${ }^{11}$ PRUS, B., Kroniki, vol. 19, ed. Z. SZWEYKOWSKI, Warsaw 1969, p. 179. 
maturely grow up and look for a way to earn their living. He wrote about the links between poverty, low culture of the parents, and the future of children who are not provided with adequate parental care or school education. He deplored the fate of boys, who "start by playing buttons, then move on to innocent lies and begging, then they bully smaller children, chase the madmen, and then, finally, they grab a knife"12. Appealing to the sense of humanity and solidarity, has asked the public to support associations taking care of and educating the neglected and poorest children. He stressed the need to develop tools of social diagnosis and methods of social and educational work. He believed that Polish society should discuss the conditions of demoralisation and youth crime. He described research on the situation of minors undertaken in Western Europe, where "thanks to the principle of not hiding evil, the public already knows that there are thirteen-year-old prostitutes, thirteen-year-old thieves, drunkards, tramps, and sixteen-year-old murderers. We are just beginning to learn about it ${ }^{13}$."

Prus was a great supporter of providing care and upbringing for children in shelters, daycare centres, halls and city gardens. The idea of establishing such institutions was shared by social and educational activists. The organisation of daycare centres for young children was considered to be a matter of fundamental importance. As early as in the 1850 s and 1860 s, the problem of providing care to "unattended" children became a regular concern of charity activists. The number of daycare centres, which were established mainly in cities and industrial settlements, was growing slowly but steadily. Their primary goal was to provide care for children at risk of "bad street influence" ${ }^{14}$. The tasks of daycare centres were discussed in a similar way in the press in the final decades of the 19th century. Centres in cities and villages were supposed to prevent accidents and demoralisation $^{15}$. At the turn of the 19th and 20th centuries, pedagogues and educational activists stressed the necessity of modernising working methods and greater care for ensuring proper development of children and preparing them for social life. The philanthropic model of daycare centres was believed to be a pedagogical anachronism, which supported and perpetuated social inequalities ${ }^{16}$. After 1905, the Child Care Society played an important role in the establishment of new daycare centres.

The forms of care and education for older children, who could no longer attend daycare centres, included activities in various types of halls established and operating at the

12 PRUS, B., "Dzieci warszawskie", Tygodnik Ilustrowany, 1905, issue 14, p. 244.

13 PRUS, B., Kroniki, vol. 20, ed. Z. SZWEYKOWSKI, Warsaw 1970, p. 80.

14 JACHOWICZ, E., “Ochrony i zakłady sierot warszawskiego Towarzystwa dobroczynności”, [in:] Niedole dziecięce, Warsaw, 1882, p. 122; FIJAŁEK, J., Instytucje pomocy materialno-zdrowotnej w Łodzi i okręgu tódzkim, Łódź 1962, p. 139-140.

15 PRUS, B., Kroniki, vol. 3, ed. Z. SZWEYKOWSKI, Warsaw 1954, p. 303-304; Idem, Kroniki, vol. 10, ed. Z. SZWEYKOWSKI, Warsaw 1960, p. 250; Idem, Kroniki, vol. 14, ed. Z. SZWEYKOWSKI, Warsaw 1964 , p. $80-81$.

${ }^{16}$ MARCHLEWSKI, J., "Korzystna filantropia”, Głos, 1901, issue 26, p. 391; G. KORCZAK, J., “Tandeta dobroczynna”, Głos, 1904, issue 11, p. 163; G. KORCZAK, J., “Od szyi pół metra”, Głos, 1904, issue 20, p. 306. 
turn of the 19th and 20th centuries in the whole Kingdom of Poland by charities, religious congregations and religious communities. Children from seven to fourteen years of age were admitted to the halls (girls' halls were usually sewing workshops). The pupils were provided with vocational training. Boys learned crafts, usually carpentry, locksmithing, tailoring, basket-weaving or leatherworking, while girls learned sewing and embroidery. At the same time, elementary teaching was carried out, often using the primer by Konrad Prószyński. Great deal of attention was paid to social, moral and patriotic education. Despite the ban imposed by the occupying powers, many such halls taught classes in Polish ${ }^{17}$.

The halls, which were aimed at the poorest and most neglected children and youth, played a significant role in care and education at the turn of the 19th and 20th centuries. They offered a viable substitute for vocational education, and the fact that they encompassed children and young people for whom no other forms of education were available made them all the more valuable. These halls developed children's skills, while fulfilling educational and pedagogical goals. Participation in classes made the child accustomed to work organisation, reliability, order and cleanliness. The pupils gained confidence in themselves, they also discovered a sense of empowerment and learnt how to work in a group. In some places, attempts were made to use the elements of slöj, develop the aesthetic sensitivity in children based on this concept, and stimulate the desired social and moral attitudes ${ }^{18}$. Educational activists emphasised the difficulties connected with implementing the principles of slöjd in working with children from the poorest families, while at the same time pointing out the need to popularize it. M. Dunin-Sulgustowska drew attention to the hardly visible influence of slöjd "on the poor children, who showed lack of skill for work" and therefore stressed that "the development of slöjd is desirable, especially in this direction. In Sweden, it is an actual ally in the fight against poverty ${ }^{19}$."

The press wrote about the utilitarian nature of the halls and sought to popularise the idea of this form of care and education in the society ${ }^{20}$. The majority of children and youth attending the workshops at the halls and working at sewing halls came from poor families and were at a risk of pathology, so providing them with something to do had a practical dimension, not only in terms of developing their professional skills, which could prove useful in adult life, but also in organising their time, shaping the passion for work and respecting $\mathrm{it}^{21}$.

17 MARKIEWICZOWA, H., Działalność opiekuńczo-wychowawcza Warszawskiego Towarzystwa Dobroczynności 1814-1914, Warsaw 2002, p. 192-204; KĘPSKI, C., Towarzystwa dobroczynności w Królestwie Polskim (1815-1914), Lublin 1993, p. 165. p. $97-98$

${ }^{18}$ Cf. GROT-BĘCZKOWSKA, W., "Slöjd, jako czynnik wychowawczy”, Bluszcz, 1902, issue 9,

19 DUNIN-SULGUSTOWSKA, M., "O slöjdzie i jego stanowisku wobec wychowania i hygieny", Zdrowie, 1905, issue 1, p. 80.

20 “Silva Rerum”, Kronika Rodzinna, 1889, issue 2, p. 63.

${ }^{21}$ Tygodnik Mód i Powieści, 1887, issue 3, p. 22. 
The idea of summer camps for the poorest children from urban environments enjoyed significant support of the society ${ }^{22}$. It was adapted for use in Poland from Western European countries. The first summer holiday camps were organised in Switzerland; in a short time, the idea of summer trips, which supported physical development of children, while also having an excellent influence on their mental and moral development, was implemented in most European countries, as well as the United States, Australia and Japan. Poles were also interested in this form of taking care for poor and neglected children, and much was written about it in the social press ${ }^{23}$. The first trip was organised in Warsaw in 1882 , in the following years summer camp campaigns were repeated in Warsaw, and at the turn of the 19th and 20th centuries trips were organised in most provincial cities ${ }^{24}$. The most important objective of summer camps was to improve the health and hygiene of children from the poorest families, but equally important was the educational dimension of trips. Children were cared for by qualified educators, they played outside and in the water, they participated in team games and wandered around the area. They got to know the beauty of nature and had the opportunity to spend their leisure time in a valuable way. The trips provided the pupils with experience and skills, enabling them to properly socialise. Participation in the summer camps helped them in the development of social competences and establishing valuable relationships in a group of their peers. Thanks to this, summer trips also served a preventive function, helping to protect children from corruption ${ }^{25}$.

22 PRUS, B., Kroniki, vol. 7, ed. Z. SZWEYKOWSKI, Warsaw 1958, p. 189-190; Idem, Kroniki, vol. 13, ed. Z. SZWEYKOWSKI, Warsaw 1963, p. 336-337; Idem, Kroniki, vol. 14, p. 286; Idem, Kroniki, vol. 15, ed. Z. SZWEYKOWSKI, Warsaw 1965, p. 8.

23 "Letnie kolonie dla dzieci", Kłosy, 1882, issue 888, p. 12-13, issue 889, p. 29-30; KOZŁOWSKI, W., "O rozpowszechnianiu kolonii letnich i ogrodów dziecięcych”, Zdrowie, 1905, issue 2, p. 172; Cf. WICHERKIEWICZ, "Poznańskie kolonie wakacyjne", Zdrowie, 1886, issue 3, p. 2-3.

${ }^{24}$ Gazeta Radomska, 1890, issue 25, p. 2; Tygodnik Ilustrowany, 1900, issue 49, p. 974; SUPADY, J., "Powstanie i rozwój kolonii letnich dla dzieci w Łodzi na przełomie XIX i XX wieku", Zdrowie Publiczne, 1977, issue 3, p. 193-198; DEMEL, M., Pedagogiczne aspekty warszawskiego ruchu higienicznego (1864-1914), Wrocław 1964, p. 137-139; SOBCZYŃSKA, M., "Kolonie letnie w Ciechocinku dla chorych dzieci z guberni płockiej”, Notatki Płockie, 2007, issue 2, p. 6-10; KĘPSKI, C., Lubelskie Towarzystwo..., op. cit., p. 88-89.

25 Educators and doctors drew attention to the social and moral importance of children's participation in summer camps. In 1899, Dr M. Berenstein published an article in Czasopismo Lekarskie, saying: "As far as moral and educational influences are concerned, probably all of those who had the opportunity to get to know their lives more closely consider it very important. Because of friendly relations, it is quite easy to get to know and influence the nature of children. Such voices are often heard in Western Europe and countries where compulsory school education has long been introduced, where almost everyone is able to read, where workers and poor craftsmen are incomparably better educated developed intellectually than our proletariat. Thus, it can be understood that the educational influence of summer camps carried out in our city should be even more prominent [...] It is only during the summer camps that such children experience the influence of people, who are to some extent trained and prepared for education; they learn order, decency, cleanliness, they also get to know the fundamental moral principles [...] almost all children return home in better shape, with some good manners and with an excellent supply of new knowledge about rural life, about work in the field, loving nature, and with expanded intellectual horizons. We can safely say that for many children, summer camps are a replacement for school. BERENSTEIN, M., "O kolonjach letnich dla ubogich dzieci w Lodzi”, Czasopismo Lekarskie, 1899, issue 9, p. 405. 
Summer camps were not able to provide care to everybody who was willing to take part. The vast majority of poor children could not participate. Educators and physicians wrote about the fatal consequences of excessively dense urban development, and thus the lack of space for playing and recreation. Attention was drawn to the need to provide children with opportunities for outdoor activities, playing freely with their peers, as well as activities aimed at improving their health, that have a significant impact on intellectual, social and moral development ${ }^{26}$. The necessity of organising generally accessible playgrounds for children in crowded cities was emphasised by outstanding educators and social activists, including Jan Władysław Dawid, Aniela Szycówna, Iza Moszczeńska, Janusz Korczak and Zygmunt Kramsztyk ${ }^{27}$. Pointing out the role of gardens, Aniela Szycówna wrote that they are particularly important in caring for neglected children, because "poor and underprivileged parents cannot and do not know how to take care of children, so they leave them to their own devices, letting them go and get exposed to the bad influence of the street, which causes early moral corruption, which exacerbates their stunted physical development ${ }^{28}$." When the children's gardens were established, references were made to organisational and pedagogical solutions employed in the West, but the gardens established in Krakow by Dr Henryk Jordan ${ }^{29}$ were considered to be the best functioning children's gardens. In the Kingdom of Poland, urban gardens were established in Warsaw, Lublin, Kalisz, Płock, Włocławek, Częstochowa and Sosnowiec. On the other hand, the lack of gardens was particularly visible in Łódź.

In 1910, A. Jaśkiewicz wrote about the position of children deprived of proper parental care, who sought support in peer groups led by charismatic teenagers with some experience in criminal activity, in Nowe Tory. He emphasised that the neglected children often became criminals, became "members of intelligence troops of various burglars or common thieves, candidates for the court in the role of the accused" ${ }^{30}$. Thinking about the ways to counteract child corruption, he described children's clubs for the "street children" in the United States and France, which were run by children themselves. He called for the

26 “Ogrody dla dzieci”, Przegląd Pedagogiczny, 1893, issue 11, p. 145-146; Biblioteka Warszawska, 1894, vol. 2, p. 195-196; SZYCÓWNA, A., “Ogród zabaw, gier i zajęć praktycznych dla dzieci”, Zdrowie, 1912, issue 8, p. 624-626; KOZŁOWSKI, W.R., “O rozpowszechnieniu kolonii letnich i ogrodów dziecięcych”, Zdrowie, 1905 , issue 2, p. 171-179.

${ }^{27}$ DAWID, J. W., "Publiczne place do zabaw dla dzieci", Przeglad Pedagogiczny, 1890, issue 14, p. $157-$ 158; MOSZCZEŃSKA, I., "Dzieci w Warszawie", Przegląd Pedagogiczny, 1898, issue 20, p. 359; SZYCÓWNA, A., "Ogrody dziecięce imienia Rau'a”, Zdrowie, 1904, issue 1, p. 3-11; TCHÓRZNICKI, J., "Ogrody do zabaw i gier dla dzieci", Przegląd Pedagogiczny, 1903, issue 22, p. 267; KORCZAK, J., "Skwery", Głos, 1904, issue 23, p. 356; KORCZAK, J., "Ogrody i skwery", Głos, 1904, issue 26, p. 402; "Kronika miesięczna”, Biblioteka Warszawska, 1898, issue 4, p. 371-378; “Z tygodnia na tydzień”, Tygodnik Ilustrowany, 1899 , issue 27, p. 519.

28 SZYCÓWNA, A., “Ogrody dziecięce imienia Rau'a”, Zdrowie, 1904, issue 1, p. 5.

${ }^{29}$ KOZŁOWSKI, W.R., "Postępy wychowania fizycznego w ostatniem dziesięcioleciu”, Zdrowie, 1908, issue $10-11$, p. 772 .

30 JAŚKIEWICZ, A., "W walce o godność człowieczą...”, Nowe Tory, 1910, issue 1, p. 7. 
establishment of similar organisations in the Kingdom of Poland. However, this concept was not implemented due to the lack of support from philanthropists.

Another particularly important problem was the organisation of institutions for children and young people, who were in conflict with the law. The inertia of the partitioning powers in this field forced social and educational activists to take responsibility for building facilities for neglected youth. This was caused by the lack of approval for the imprisonment of minors, as well as the belief that they required care and education. Corrective institutions for socially maladjusted children and young people were established in all European countries. Polish social activists observed their operations during their travels abroad. Expert magazines, as well as social and cultural press in Poland discussed the facilities known as the best ones in the world, including Mettray near Tours, the facility in the Rÿsselt estate near Zutphen in the Netherlands, the correctional establishment in Marienhof near Dresden, the house for juvenile offenders and neglected children in Horn near Hamburg, and the Italian agricultural colonies (for example in Monkukko), as well as facilities in Belgium and Switzerland ${ }^{31}$. Drawing upon the experience of facilities which operated as agricultural and crafts settlements, a law was drafted and the Polish Society of Agricultural and Crafts Settlements was established in 1871 in the Kingdom of Poland. The goal of the newly created institution was to work on "the moral betterment of children of both sexes, who were sentenced to punishment by the court for their crimes, or to improve the fate of underage beggars and vagrants without shelter ${ }^{32}$." The Society was to establish agricultural settlements and crafts institutions providing elementary education and practical job training.

In May 1876, a settlement for boys was opened in Studzieniec. A family and grade system comprising of five grades was adopted. Each of the grades had its own educator and occupied a separate house in the settlement ${ }^{33}$. Groups were dubbed families and educators were called family fathers ${ }^{34}$. The adopted system of group education was a method of social rehabilitation and building social bonds. The foundation of penitential influence was moral and religious education, the youth were also made sure to be physically active. The wards were educated at the elementary level. It was difficult to broaden the scope of theoretical knowledge due to the intellectual abilities of boys going to the facility. Most of

31 “Osada rolniczo-karna w Mettray”, Biblioteka Warszawska, 1843, issue 4, p. 772-778; MOLDENHAWER, A., "Krótka wiadomość o pierwszych osadach rolnych i o ich założycielach", Kłosy, 1874, issue 479, p. 158-159, issue 480; p. 172-174; MOLDENHAWER, A., "O zakładach karnych dla nieletnich przestępców i dzieci potrzebujących opieki”, Przegląd Sądowy, 1871, vol. 10, p. 159-203; DASZYŃSKA-GOLIŃSKA, Z., "Ochrona dzieci we Francji”, Prawda, 1908, issue 47, p. 573; issue 48, p. 586.

32 DUKACZEWSKI, E. J., "Szkoły i zakłady specjalne dla dzieci trudnych w XIX i na początku XX wieku”, [in:] Dzieje szkolnictwa i pedagogiki specjalnej, ed. S. MAUERSBERG, Warsaw 1990, p. 138.

33 "Studzieniec", Gazeta Sąowa Warszawska, 1882, issue 22, p. 175-178; RAŚ, D., Rodziny ubogie i przestępczość od XVI do XX wieku. Warunki życia, badania psychologiczno-społeczne, dobroczynność $i$ wychowanie młodzieży, Kraków, 2011, p. 70.

${ }^{34}$ Regarding the organisation and methodology of education work in Studzieniec, see: MOLDENHAWER, A., "Towarzystwo osad rolnych i przytułków rzemieślniczych oraz jego zakłady", [in:] Niedole dziecięce, Warsaw 1882, p. 211-235. 
them were illiterate. On the other hand, vocational education was at a high level. Each of the Studzieniec wards got acquainted with farm work and then with one of the basic crafts: carpentry, wheelwrighting, coppersmithing, joinery, etc, allowing them to gain skills necessary to work in agriculture and crafts $^{35}$. The system of care for boys leaving the facility was also well developed. They were given financial support and placed with trustworthy craftsmen. In the case of wards from particularly corrupted backgrounds, foster guardians were sought to take care of those leaving the facility ${ }^{36}$. Up to 1881, out of the 97 children released, 16 were returned under the custody of their parents and 68 were placed with foster guardians ${ }^{37}$. During the first twenty years of its existence, the settlement in Studzieniec has "made a difference to society by raising 890 minors" 38 . It was believed that it would serve as a model for further establishments for children and young people at risk of demoralisation, that these institutions would solve a number of social problems - they would prevent vagrancy, begging and crime ${ }^{39}$. Experts in the field of law, psychology, pedagogy from the Kingdom of Poland and other Polish lands, as well as from other European countries were coming to Studzieniec ${ }^{40}$. In 1891, in the village of Puszcza Mariańska a new establishment for girls was opened by the Society.

Another valuable project was the establishment of a facility for boys in Struga near Warsaw by the "Patronage" Association for the Care of Prisoners, providing social and moral education, as well as professional training. The institution, which was called the School of Labour, was intended for 40 boys aged 12 to 17 , released from prisons. The wards gained practical skills in shoemaking, weaving and carpentry workshops. They were taught writing, reading, mathematics and history of Poland ${ }^{41}$.

Care and education activities were also addressed towards girls running a risk of becoming prostitutes and towards underage prostitutes. The scale of needs in this area was very extensive; it is enough to recall that in industrial cities, girls as young as 10-12 years old engaged in prostitution ${ }^{42}$. The most famous shelter for prostitutes was the so-called Centre for Care of the Blessed Virgin Mary (the so-called "Magdalenka") on Żytnia Street

35 “Nieletni przestępcy”, Gazeta Sądowa Warszawska, 1877, issue 14, p. 111.

${ }^{36}$ Cyvol. after: SZYMAŃSKA, H., “Z problemów przestępczości nieletnich w drugiej połowie XIX wieku", Przeglad Penitencjarny, 1964, issue 2, p. 140.

37 “Studzieniec”, Gazeta Sądowa Warszawska, 1882, issue 22, p. 176.

38 “Silva Rerum”, Kronika Rodzinna, 1896, issue 6, p. 188.

39 PRUS, B., Kroniki, vol. 1, part 2, ed. Z. SZWEYKOWSKI, Warsaw 1956, p. 15-16; Idem, Kroniki, vol. 2, ed. Z. SZWEYKOWSKI, Warsaw 1953, p. 204; p. 499; Idem, Kroniki, vol. 4, ed. Z. SZWEYKOWSKI, Warsaw 1955, p. 284-285; Idem, Kroniki, vol. 7..., p. 274; Idem, Kroniki, vol. 11, ed. Z. SZWEYKOWSKI, Warsaw 1961, p. 180-181.

40 “Trzeci Zjazd przedstawicieli zakładów poprawczych w Moskwie”, Gazeta Sąowa Warszawska, 1890, issue 36 , p. 573-574, issue 37 ; p. 589-590.

${ }^{41}$ ZBYSZEWSKA, Z., Ministerstwo polskiej biedy. Z dziejów Towarzystwa Opieki nad Więźniami "Patronat" w Warszawie 1909-1944, Warsaw 1983, p. 32-33.

42 KAMIŃSKI, J.M., O prostytucji, Warsaw 1975, p. 135; MARGULIES, B., "Prostytucya w Łodzi", Zdrowie, 1906, issue 8, p. 539-547. 
in Warsaw. From 1862 it was led by the Congregation of the Sisters of Our Lady of Mercy, founded by Ewa Potocka, nee Sułkowska, who learned the methods of socialisation work in a French institution for prostitutes in Laval. The same congregation set up several more facilities for girls and prostitutes at risk of corruption. From 1881 in Derdy, in the Piaseczno district, there was a shelter dubbed "the house of St Joseph" or "Józefowo". In 1899 in Płock, the sisters of the Congregation of Our Lady of Mercy joined the local Congregation of "Divine Love", which established a shelter, founded in 1889 on the inspiration of Jakobina Łabanowska and Father Antoni Nowowiejski, called the Guardian Angel Facility. In Częstochowa, the congregation established a shelter for prostitutes in 1908. On the eve of regaining independence by Poland, another facility for prostitutes was established in the Kingdom, this time in Radom ${ }^{43}$.

The shelter for morally decadent girls, which has been functioning since 1897 as the St. Margaret Shelter, was established in 1895 by Ludwika Moriconi ${ }^{44}$. In Ciechanów, the Congregation of Sisters Servants of Mary Immaculate (Servants) took care of the "fallen girls". Operating from 1883 to circa 1890, the "morally endangered" girls' shelter in Lublin was supported by the Congregation of the Franciscan Sisters of Suffering (Franciscans). In 1895, in Lublin, St. Anthony's Institution - another shelter for girls and women who wanted to abandon prostitution - was established by Father Ignacy Kłopotowski ${ }^{45}$. It is difficult to determine what methods and forms of work were used in the facilities operated by religious congregations. It is known that among the methods of resocialisation used in the facilities were work, prayer and participation in religious celebrations ${ }^{46}$. The wards of these shelters also worked, learned sewing, embroidery and laundry. No further information was provided. This provoked criticism of the public, who did not like the isolation of these facilities, especially visible in the case of "magdalenki" 47.

At the turn of the 19th and 20th centuries, many organisations were founded by secular social activists in order to take care of girls and protect them from moral corruption and prostitution. The Christian Society for the Protection of Women was established in $1902^{48}$. Its local branches were located in Łódź, Radom, Włocławek, Częstochowa, Lublin, Piotrków, Płock and Kielce ${ }^{49}$. The Society gathered people of Catholic and Lutheran faiths.

${ }^{43}$ BAR, J., "Rozwój stanów doskonałości w Polsce. Zgromadzenie Matki Bożej Miłosierdzia (18621962)", Prawo Kanoniczne, 1966, issue 3-4, p. 41-47, 64-88.

44 “Warszawski Dom Schronienia św. Małgorzaty”, Czystość, 1905, issue 6, p. 1.

45 KĘPSKI, C., Lubelskie Towarzystwo..., p. 90.

46 St. hr Al., "Dla upadłych”, Kurier Warszawski, 1881, issue 251, p. 2.

${ }^{47}$ KAMIŃSKI, J.M., O prostytucji..., p. 210-212. Cf. Poseł Prawdy, ŚWIĘTOCHOWSKI, A., "Liberum veto", Prawda, 1881, issue 47, p. 562.

48 "Nad otchłanią", Gazeta Sądowa Warszawska, 1902, issue 13, p. 196-198; Biblioteka Warszawska, 1902, issue 2, p. 169 ff.; "Towarzystwo Ochrony Kobiet", Tygodnik Mód i Powieści, 1902, issue 51, p. 605606; MAZUR, E., Dobroczynność w Warszawie XIX wieku, Warsaw 1999, p. 30; "Warszawskie chrześcijańskie Towarzystwo ochrony kobiet", Czystość, 1909, issue 33-34, p. 524-525.

49 Kalendarz Informacyjno-Encyklopedyczny na rok 1914, p. 572-575; VIII Międzynarodowy Kongres Komitetów Walki z handlem kobietami i dziećmi, Warsaw 1930, p. 33-34. 
It conducted educational campaigns and established a few centres for girls and women. In 1904, a Jewish Society for the Protection of Women was established, later referred to as the Warsaw Jewish Society for the Protection of Women ${ }^{50}$. It established a shelter, ran a job centre, a centre for girls, a cheap kitchen, and provided grants and loans. A separate organisation pursuing similar goals was the Jewish Society for the Protection of Women in $Ł o ́ d z^{51}$. At the turn of the 19th and 20th centuries, associations were also set up to provide care and education for girls and young women to prepare them for adult life and help them find decent work. An example of such organisation is the Evangelical-Augsburg Association for the Care of the Virgins, registered in 1898. Local branches were established in Łódź, Pabianice, Tomaszów Mazowiecki and Zduńska Wola ${ }^{52}$. In Łódź, in 1903, the Association of Evangelical Virgins was established at St. John's Church, which took care for the religious and social and moral education of its wards. On Sunday and holidays, the girls gathered in the parish daycare centre, where they crafted and read the Holy Scriptures and religious books collected in a library run by the Association. The organisation also helped the girls to find a job and a place to live. The Society for the Care of the Virgins in Ozorków, established in 1909, provided moral support for their wards ${ }^{53}$. The lack of financial resources prevented many organisations from developing their activities. Their founders wrote about many interesting concepts of care, upbringing and educational activities, which could not be fully realised in the realities of the Kingdom of Poland ${ }^{54}$.

We need to ask ourselves a question - to what extent were the theoretical concepts and activity models of care and educational institutions in the Kingdom of Poland a product of an independent, original Polish thought or transferring Western models on the Polish ground? Were the existing conditions not conducive to dependentism ${ }^{55}$ ? Did getting to know foreign ideas and solutions inspire the people to create their own concepts? It is difficult to give an unambiguous answer to these questions, but an analysis of the activities of many associations and institutions shows that their founders have creatively adapted Western European models. On the basis of these experiences many original concepts were created. Many Polish activists developed their own methods of working with children and young people, adapted them to local needs and opportunities, basing them on the theo-

50 “Kronika. Wiadomości społeczne”, Prawda, 1904, issue 33, p. 395; VIII Międzynarodowy..., p. 55.

${ }^{51}$ SIKORSKA-KOWALSKA, M., WIATR, E., "Łódzkie Żydowskie Towarzystwo Ochrony Kobiet w Łodzi 1914-1939", Studia z Historii Spoleczno-Gospodarczej XIX i XX w., 2008, issue 5, p. 328 ff.

52 "Ewangelicko-augsburskie Stowarzyszenie opieki nad dziewicami w Warszawie", Zwiastun Ewangeliczny, 1899, issue 6, p. 175-176.

53 JAWORSKI, W., Przemiany legalnego życia społecznego w Królestwie Polskim w latach 1864-1914, Sosnowiec 2006, p. 259.

54 The needs and areas of activity were widely discussed in progressive social press and women's magazines, including Ogniwo, Ster, Czystość, Głos, Prawda, Bluszcz.

55 Dependentism manifests itself in the $a$ priori assumption that the values presented by the external environment are more important and important than the norms and values adopted in one's own environment, which is depreciated, considered to be peripheral and obscurant. Cf. KRZYWICKI, L., "Jeden z pogromców", [in:] idem, Dzieła, vol. 9, ed. H. HOŁDA-RÓZIEWICZ, Warsaw, 1974, p. 51. 
retical reflections of Polish pedagogues, including Jan Władysław Dawid and Stanisław Karpowicz. Another thing is that the need to adapt to the difficult political and economic realities of the Kingdom of Poland somewhat ruled out the risk of dependentism. Polish social workers, operating in completely different conditions, had to face the problems that Western European organisations did not have to deal with, and their actions required much deeper involvement. As a result of deliberate laissez-faire approach in the field of care, and partly also as a result of educational policies of the partitioning powers, the issues of care and upbringing of the poorest and neglected children remained almost entirely within the sphere of social activities. Constant financial and housing difficulties, as well as hardships on the part of tsarist officials led to a situation that in many cases the necessity of taking care of organisational issues made it difficult to implement the formulated educational concepts. Some of them were implemented only in independent Poland.

\section{Works cited}

Al. hr S., "Dla upadłych, Kurier Warszawski, 1881, issue 251

BAR J., "Rozwój stanów doskonałości w Polsce. Zgromadzenie Matki Bożej Miłosierdzia (18621962)", Prawo Kanoniczne, 1966, issue 3-4

BERENSTEIN M., "O kolonjach letnich dla ubogich dzieci w Łodzi”, Czasopismo Lekarskie, 1899 , issue 9

Biblioteka Warszawska, 1894, vol. II

Biblioteka Warszawska, 1902, issue 2

BOŁDYREW A., "Społeczne inicjatywy na rzecz walki z patologiami w Królestwie Polskim na przełomie XIX i XX w." Studia Gdańskie, vol. XXXI, 2012

D. J.Wł. [DAWID J.W.], "Publiczne place do zabaw dla dzieci”, Przegląd Pedagogiczny, 1890, issue 14

DASZYŃSKA-GOLIŃSKA Z., “Ochrona dzieci we Francji”, Prawda, 1908, issue 47 - 48.

DEMEL M., Pedagogiczne aspekty warszawskiego ruchu higienicznego (1864-1914), Wrocław, 1964

DUKACZEWSKI E.J., "Szkoły i zakłady specjalne dla dzieci trudnych w XIX i na początku XX wieku", [in:] Dzieje szkolnictwa i pedagogiki specjalnej, ed. S. Mauersberg, Warsaw, 1990

DUNIN-SULGUSTOWSKA M., "O slöjdzie i jego stanowisku wobec wychowania i hygieny", Zdrowie, 1905, issue 11

"Ewangelicko-augsburskie Stowarzyszenie opieki nad dziewicami w Warszawie", Zwiastun Ewangeliczny, 1899, issue 6

FIJAŁEK J., Instytucje pomocy materialno-zdrowotnej w Łodzi i okręgu łódzkim, Łódź, 1962

g. [KORCZAK J.], "Od szyi pół metra”, Gtos, 1904, issue 20

g. [KORCZAK J.], "Ogrody i skwery”, Gtos, 1904, issue 26

g. [KORCZAK J.], "Skwery”, Gtos, 1904, issue 23

G. [KORCZAK J.], "Tandeta dobroczynna", Glos, 1904, issue 11

Gałek C., Myśl pedagogiczna Bolesława Prusa na tle pozytywizmu polskiego, Zamość, 2005

Gazeta Radomska, 1890, issue 25

GROT-BĘCZKOWSKA W., "Slöjd, jako czynnik wychowawczy”, Bluszcz, 1902, issue 9

HEYWOOD C., "Childhood and Children", [in:] Europe 1789 to 1914: Encyclopedia of the Age of INDUSTRY and Empire, J. MERRIMAN, J. WINTER (eds.), vol. 1, Thomson Gale, Detroit, 2006 
JACHOWICZ E., “Ochrony i zakłady sierot warszawskiego Towarzystwa dobroczynności”, [in:] Niedole dziecięce, Warsaw, 1882

JASTRZĘBIEC A., "Przytułek wychowawczo-poprawczy dla dziewcząt", Tygodnik Mód i Powieści, 1891, issue 13

JAŚKIEWICZ A., "W walce o godność człowieczą...", Nowe Tory, 1910, issue 1

JAWORSKI W., Przemiany legalnego życia społecznego $w$ Królestwie Polskim w latach 1864 1914, Sosnowiec, 2006

Kalendarz Informacyjno-Encyklopedyczny na rok 1914, Warsaw, 1914

KAMIŃSKI J.M., O prostytucji, Warsaw, 1875

KĘPSKI C., Towarzystwa dobroczynności w Królestwie Polskim (1815-1914), Lublin, 1993

Kongres Komitetów Walki z handlem kobietami i dziećmi, Warsaw, 1930

KORCZAK J., Dzieci ulicy, Warsaw, 1901

KOZŁOWSKI W., "O rozpowszechnianiu kolonii letnich i ogrodów dziecięcych”, Zdrowie, 1905, issue 2

KOZŁOWSKI W.R., "Postępy wychowania fizycznego w ostatniem dziesięcioleciu”, Zdrowie, 1908, issue $10-11$

"Kronika miesięczna", Biblioteka Warszawska, 1898, issue 4

"Kronika. Wiadomości społeczne", Prawda, 1904, issue 33

KRZYWICKI, L., “Jeden z pogromców”, [in:] idem, Dzieła, vol. IX, ed. H. HOŁDA-RÓZIEWICZ, Warsaw, 1974

L. L., "Pozbawienie rodziców władzy rodzicielskiej”, Gazeta Sąowa Warszawska, 1890, issue 15

"Letnie kolonie dla dzieci", Kłosy, 1882, issue 888-889

M. A., "Ograniczenie władzy rodzicielskiej. Skutki wyroków karnych zagranicznych", Gazeta Sąowa Warszawska, 1896, issue 13

M. J. (MARCHLEWSKI J.), "Korzystna filantropia”, Głos, 1901, issue 26

MARGULIES B., Prostytucya $w$ Lodzi, "Zdrowie" 1906, issue 8

MARKIEWICZOWA H., Działalność opiekuńczo-wychowawcza Warszawskiego Towarzystwa Dobroczynności 1814-1914, Warsaw, 2002

MAZUR E., Dobroczynność w Warszawie XIX wieku, Warsaw, 1999

MOGILNICKI A., Dziecko i przestępstwo, Warsaw, 1916

MOLDENHAWER A., "Domy moralnie zaniedbanych dzieci", Zdrowie, 1896, issue 5-7

MOLDENHAWER A., "Krótka wiadomość o pierwszych osadach rolnych i o ich założycielach", Kłosy, 1874, issue 479-480

MOLDENHAWER A., "O zakładach karnych dla nieletnich przestępców i dzieci potrzebujących opieki”, Przeglad Sądowy, 1871, vol. 10

MOLDENHAWER A., "Stowarzyszenia i instytucye zagraniczne opiekujące się dziećmi”, [in:] Niedole dziecięce, Warsaw, 1882

MOLDENHAWER A., "Towarzystwo osad rolnych i przytułków rzemieślniczych oraz jego zakłady", [in:] Niedole dziecięce, Warsaw, 1882

MOSZCZEŃSKA I., "Dzieci w Warszawie”, Przeglad Pedagogiczny, 1898, issue 20

"Nad otchłanią", Gazeta Sądowa Warszawska, 1902, issue 13

"Nieletni przestępcy”, Gazeta Sąowa Warszawska, 1877, issue 14

"Ogrody dla dzieci", Przeglad Pedagogiczny, 1893, issue 11

ORZESZKOWA E., "O niedolach dziecięcych, Tygodnik Ilustrowany, 1876, issue 15

"Osada rolniczo-karna w Mettray", Biblioteka Warszawska, 1843, issue 4

PIETKIEWICZ Z., "Opieka społeczna. Dzieci”, Prawda, 1900, issue 47

POŁKOTYCKI W., "Domy sierot”, Zdrowie, 1896, issue 5-7

Poseł Prawdy [ŚWIĘTOCHOWSKI A.], "Liberum veto", Prawda, 1881, issue 47

PRUS B., "Dzieci warszawskie", Tygodnik Ilustrowany, 1905, issue 14

PRUS B., Kroniki, ed. Z. Szweykowski, vol. I-XX, Warsaw, 1953-1970 
RAŚ D., Rodziny ubogie i przestępczość od XVI do XX wieku. Warunki życia, badania psychologiczno-spoleczne, dobroczynność i wychowanie młodzieży, Kraków 2011

SIKORSKA-KOWALSKA M., WIATR E., "Łódzkie Żydowskie Towarzystwo Ochrony Kobiet w Łodzi 1914-1939", Studia z Historii Społeczno-Gospodarczej XIX i XX w., 2008, issue 5

"Silva Rerum", Kronika Rodzinna, 1889, issue 2

"Silva Rerum", Kronika Rodzinna, 1896, issue 6

SOBCZYŃSKA M., "Kolonie letnie w Ciechocinku dla chorych dzieci z guberni płockiej”, Notatki Plockie, 2007, issue 2

"Studzieniec", Gazeta Sądowa Warszawska, 1882, issue 22

SUPADY J., "Powstanie i rozwój kolonii letnich dla dzieci w Łodzi na przełomie XIX i XX wieku, Zdrowie Publiczne, 1977, issue 3

SZYCÓWNA A., "Ogrody dziecięce imienia Rau'a", Zdrowie, 1904, issue 1

SZYCÓWNA A., "Ogród zabaw, gier i zajęć praktycznych dla dzieci”, Zdrowie, 1912, issue 8

SZYMAŃSKA H., "Z problemów przestępczości nieletnich w drugiej połowie XIX wieku", Przeglad Penitencjarny, 1964, issue 2

TCHÓRZNICKI J., "Ogrody do zabaw i gier dla dzieci”, Przegląd Pedagogiczny, 1903, issue 22

"Towarzystwo Ochrony Kobiet", Tygodnik Mód i Powieści, 1902, issue 51

"Trzeci Zjazd przedstawicieli zakładów poprawczych w Moskwie”, Gazeta Sądowa Warszawska, 1890 , issue $36-37$

Tygodnik Ilustrowany, 1900, issue 49

Tygodnik Mód i Powieści, 1887, issue 3

VIII Międzynarodowy Kongres Komitetów Walki z handlem kobietami i dziećmi, Warsaw, 1930.

"W obronie dzieci", Gtos, 1904, issue 17

"Warszawski Dom Schronienia św. Małgorzaty", Czystość, 1905, issue 6

"Warszawskie chrześcijańskie Towarzystwo ochrony kobiet", Czystość, 1909, issue 33-34

Wicherkiewicz, "Poznańskie kolonie wakacyjne", Zdrowie, 1886, issue 3

"Z tygodnia na tydzień", Tygodnik Ilustrowany, 1899, issue 27

“Z życia stowarzyszeń. Opieka nad dziećmi”, Głos, 1897, issue 3

ZBYSZEWSKA Z., Ministerstwo polskiej biedy. Z dziejów Towarzystwa Opieki nad Więźniami "Patronat" $w$ Warszawie 1909-1944, Warsaw, 1983 